\title{
Title: On body and culture - medicine and embodiment.
}

\author{
Author: Zsuzsanna Szél M.D., Semmelweis University, Budapest
}

Funding information: No funding was received for developing the content of this article.

Declaration of Conflicting Interests: The author declare that there is no conflict of interest.

Embodiment theory shows up in several fields of (clinical) medicine, it has been applied in studying various diseases, conditions, and treatments. The aim of this short review - due to its extent limitation - is to provide some insight into the diversity of interpretation and application of the embodiment paradigm within medicine.

The question of embodiment was often discussed regarding diseases and conditions with physical modifications or lesions, as well as in case of those with notable changes in perception (e.gpregnancy, cancer or organ transplantation). However, studies were also performed in seemingly distant areas such as psychiatry (schizophrenia, dementia, depression, anorexia), pulmonology (asthma and COPD), or endocrinology (perimenopause).

Meanwhile embodiment was most frequently explored in connection with the lived experience of femininity-masculinity, physical symptoms, movement limitations, altered body sensations, some of these articles discussed more general concerns such as therapeutic relationship, (disease) perceptions, compliance and therapeutic efficiency.

Key words: embodiment, medicine, body, illness, perception 


\section{Testet öltött kultúra - orvostudomány és embodiment.}

Az embodiment elméletet az orvostudomány számos területe használja, jelenségét változatos betegségekkel, állapotokkal, kezelésekkel összefüggésben vizsgálja. Jelen tanulmánynak célja - terjedelmi limitációból és review jellegéből adódóan - egyfajta betekintést nyújtani az embodiment paradigma orvostudományi területeken történő változatos megjelenésének, értelmezésének és alkalmazásának sokszínűségébe.

$\mathrm{Az}$ áttekintett szakirodalomban számos esetben testi torzulásokkal, változásokkal, vagy megváltozott észleléssel, érzékeléssel járó kórképek és állapotok voltak a fókuszban (például várandósság, tumorok vagy szerv transzplantáció), de egészen távolinak tünő területeken is történtek vizsgálatok, mint például a pszichiátria (skizofrénia, demencia, depresszió vagy anorexia), a pulmonológia (asztma és COPD), vagy az endokrinológia (perimenopauza).

A testi elváltozásokkal járó állapotokkal és betegségekkel összefüggő vizsgálatok a nőiességférfiasság, a testi tünetek, megváltozott testérzetek megélésével foglalkoztak, míg az általánosabb kérdéseket szemléző publikációk a terápiás kapcsolatot, a (betegség) megértést, a compliance-t, illetve terápiás hatékonyságot is érintették.

Kulcsszavak: megtestesülés, orvoslás, test, betegség, észlelés 
Az orvostudományi területeket érintő tanulmányok az embodiment paradigmát számos megközelítésből tárgyalják és alkalmazzák a neurobiológiai vizsgálatoktól a fenomenológiai értekezésekig. Hagyományosan az orvoslás feladata a betegségek kiváltó okainak beazonosítása és a test (mint tárgy) korrekciója, szabályos működésének helyreállítása. Ebben a helyzetben az orvos sok esetben a testet és a betegséget a betegről és annak életkörülményeiről lehasítva kezeli (Leder 1984). A test puszta tárgyként, darabokra szedhető gépezetként történő értelmezése teret ad(ott) a test objektivizált tudományos vizsgálatának és lehetőséget jelent(ett) a részek és a müködések megismerésére, a fiziológiai folyamatok kísérletes modellezésére (Leder 1984). Létrehozta az illúziót, hogy az emberi test müködése teljességében megismerhető és az esetleges eltérések, kisiklások az egyensúly mechanikus helyreállításával megoldhatók (Leder 1984, Ussher 2008). Az embodiment elmélete az orvosi hivatásban éppen ennek a dualista testfelfogás kritikájának tekinthető.

Az embodiment paradigma szerint a test párhuzamosan van jelen tárgyi valójában környezetében, tart kapcsolatot a körülötte lévő világgal, észleli és értelmezi azt, egyfajta dinamikus kölcsönhatásban. Māra Grīnfelde a testiesülés négy egymással kölcsönös összefüggésben lévő dimenzióját különíti el a betegségek megtestesülését tárgyaló tanulmányában: (1) az affektív test maga az érző, észlelő, megélt testi tapasztalat; (2) az anyagi test, a saját testnek, mint anyagi dolognak a megtapasztalása, amely betegségek esetén éppen a magától értetődőségének elvesztése miatt kerül a figyelem fókuszába; (3) a cselekvő test a képességek, vagy a betegségek kontextusában, a "képtelenségek", elveszett, nehezített, akadályozott cselekvések színtere; (4) a társadalmi test, a mások által érzékelt test, amely kitett a társadalmi normák és elvárások hatásának. Érdemes megjegyezni ugyanakkor, hogy az észlelés, érzékelés minden dimenzióban egymással kölcsönhatásban, továbbá kulturális és történeti / történelmi, társas kontextusban konstruálódik (Leder 1984; Argentieri 2018; Grīnfelde 2018).

\section{A megtestesülés dimenziói az orvostudományi publikációkban}

Az embodiment egyes betegségekkel kapcsolatban a tünetek megélésének jobb megértését, valamint megjelenésük értelmezését szolgálja. A schizophrenia, mint a megtestesülés zavara, a megtestesült énnel való kapcsolat fellazulása, az öntudat csökkenése, a külvilággal való megtestesült kapcsolat sérülése jellemezhető (Bovet és Parnas 1993; Fuchs és Schlimme 2009). A sérült affektív testiesülés, a szenzoros ingerek feldolgozási problémái miatt a betegek túlárasztódnak az ingerek részleteivel, amelyeket nem tudnak kontextushoz kötni, és amelyek 
forrása nem egyértelmü számukra, ezért nem képesek észlelésüket koherenssé tenni és értelmezni (Bovet és Parnas 1993; Fuchs és Schlimme 2009; Tschacher, Giersch és Friston 2017). A test kihegyezett inspekciója miatt az észlelés - általában tudattalanul zajló - folyamatai tudatosulnak, amik elősegítik további jellemző schizophrenia tünetek - az elidegenedés és a széttöredezettség érzés - kialakulását (Fuchs és Schlimme,1 2009; Tschacher, Giersch és Friston 2017).

A schizophreniával szemben a depresszió affektív embodiment szempontjából éppen a test fokozott embodimen-jeként leírható. A depressziós test elveszíti a fluiditását, magától értetődőségét, nehézzé, szilárddá, materiálissá válik (Fuchs és Schlimme 2009; Aho 2013). A motiváció, a libidó, az étvágy elvész, az észlelés beszükül a testre és annak szoros környezetére, az automatizmusok megszűnnek észrevétlennek lenni, minden erőfeszítéssé válik, a testet önsúlya belebetonozza a jelen mozdulatlanságába, amely motoros gátlás olykor annyira erős lesz, hogy stupor állapotát alakítja ki (Fuchs Schlimme 2009; Aho 2013). A depressziós betegek magukat tárgynak, eltárgyiasultnak, érzésektől mentesnek észlelik, saját testüket élettelennek, nem valósnak élik meg (Fuchs és Schlimme 2009; Aho 2013).

A test módosulásával, fizikális szinten megjelenő testi változásokkal együtt élők (tumorok vagy szervátültetés) esetén a feldolgozott tanulmányokban az embodiment fókusza jellemzően a test materiális dimenziója.

A daganatok megtestesülését jellemzően a korábban kontrolláltnak, jól határoltnak megélt test határtalanná, kontrollálhatatlanná, amorffá és alávalóvá válása jellemzi (Waskul és van der Riet 2002; Solbrække és Bondevik 2015; Hopwood és Hopwood 2019; Parton, Ussher és Perz 2015). A betegség megtestesülése és a kezelések rengeteg szenvedést és nehéz testi érzést okoznak, ezért a tumoros betegek teste, mint a tumor hordozója és az orvosi beavatkozások/kezelések elszenvedője gyakran leválasztódik “énjükről”, mint a kontrollálhatatlan "másik" (Waskul és van der Riet 2002). A hegek és egyéb fizikális emlékeztetők, az egyszer árulóvá és alávalóvá vált test megbízhatatlansága, a test magától értetődőségének és könnyedségének megszünése a gyógyulást követően is elkíséri a túlélőket (Waskul és van der Riet 2002).

Szöveti szinten megváltozott materiális embodimentet jelent a szerv- és szövettranszplantáció. Miközben recipiens oldalon a test egységének megbomlása a testben megjelenő “idegen tárgy” (átültetett szerv) jelenléte tekinthető a megváltozott materiális embodiment egyik fö 
aspektusának, a szervdonorok számára Greenwood interjúlanyai szerint nagy jelentőséggel bír a mütéti heg, mint a donorélmény megtestesült szimbóluma ((De Pasquale, Veroux, Indelicato, Sinagra, Giaquinta, Fornaro, Veroux és Pistorio 2014; Schlebusch, Pillay és Louw 1992; Greenwood 2011). A graft testiesülése és integrációja hosszú folyamat, amely kezdetben az idegen szövet/szerv és a test folyamatos intenzív megfigyelésével, továbbá szorongással jár majd kedvező esetben a transzplantált szövet/szerv - különböző mértékben - kikerül a kihegyezett figyelem fókuszából és a "szokott", a "normál” testi észlelés részévé válik (De Pasquale, Veroux, Indelicato, Sinagra, Giaquinta, Fornaro, Veroux és Pistorio 2014). A transzplantáció embodied tapasztalatát gyakran jellemzik idegenség/másság érzéssel, ami hangsúlyos a kommunikációban, az észlelésben, az önkifejezésben használt testrészek/szervek testiesülése esetén (Bahler 2019; Lafrance 2010).

Hasonlóan megváltozott testiesülés a várandósság állapota, amely egy új észleléssel is gazdagabbá teszi testi tapasztalatokat: egy másik által, mégis a saját szervezeten belül testiesülő érintés tapasztalatával (Stähler 2017). A várandósok testi folyamatairól, magzatmozgásokról szóló beszámolóiban a magzat jelenléte és észlelése nem konkrét, másik lényként kerül megtapasztalásra, hanem a testek határainak feloldódásával, egyfajta fluid tapasztalatként jelenik meg, amelyben a várandós test és a magzati test együtt vesznek részt (Ross 2019). A várandós test (át)alakulása, megjelenése és megélése erős - kulturálisan és medikálisan meghatározott - elvárásoknak, elképzeléseknek van kitéve (Stähler 2017; Neiterman 2013). Míg korábban a saját testi tapasztalatok - a tapintás és a testi érzetek - szolgáltak a várandósság elsődleges észlelési jeleiként, most a képalkotó vizsgálatok segítségével, a várandósok gyakran külső vizsgálatok, klinikai eljárások keretében ismerik meg testi változásaikat (Ross 2019; Stähler 2017). A várandós test - és az arra vonatkozó külső elvárások - megzavarják szokásos tevékenységeket, befolyásolják a térben való boldogulást és beszükítik a lehetőségre álló teret (és mozgás készletet) (Neiterman 2013; Stähler 2017). A várandósgondozás alatt testi/szomatikus tapasztalataikat biomedicinális normákhoz viszonyítva figyelik meg, ami gyakran szorongással, bizonytalansággal töltheti el őket, ugyanakkor a fokozott figyelemnek köszönhetően közelibb és harmonikusabb kapcsolatot is segíthet kialakítani saját testükkel (Neiterman 2013; Ross 2019; Stähler 2017).

Más testi változásokkal, állapotokkal, vagy betegségekkel foglalkozó tanulmányok a cselekvő testre fókuszálnak és orvosi területen gyakran kognitív, neurológiai megközelítések kapnak nagyobb hangsúlyt. 
Parkinson ${ }^{1}$ szindrómával élők számára a remegés, az izommerevség és az on-off állapotok váltakozása miatt a rutinszerű mozgások konkrét kivitelezése is sokszor tudatos figyelmet igényel, ezért a testre fordított figyelem a mindennapok során is kihegyezetté válik (Gibson és Kierans 2017). A mozgások testiesülésének zavarát okozó remegés ugyanakkor csökken mind aktív mozgás, mind mozgással kapcsolatos kifejezések olvasása és feldolgozása során tremor domináns PD betegeknél, amely az életvitelük és cselekvő testiesülésük szempontjából további vizsgálatok fontos fókuszául szolgálhat (Nisticò, Cerasa, Olivadese, Dalla Volta, Crasà, Vasta, Gramigna, Vescio, Barbagallo, Chiriaco, Quattrone, Salsone, Novellino, Arabia, Nicoletti, Morelli és Quattrone 2019). A betegek beszámolóiban ugyanakkor a legnagyobb jelentőséggel bíró tünetek jellemzően nem a leggyakoribb, hanem a társadalmi szerepek betöltését leginkább fenyegető tünetek voltak (inkontinencia, remegés, meglassultság, fáradékonyság), amelyek a nemi szerepelvárások kulturális beágyazottságától nem elválaszthatók (Gibson és Kierans 2017).

A demencia orvosbiológiai modell szerint az agy betegsége, ugyanakkor mind a betegség, mind a tünetek megértése és kezelése szempontjából fontos, hogy a demencia - mint diagnózis megtestesülése az ellátórendszer szoros szabályozásának alávetve, a praktikum és protokoll keretein belül, történeti és társadalmi hatásoktól terhelten jön létre (Kontos és Martin 2013). A szelf-élmény csökkenése dementiában Fuchs (2020) szerint nem a szubjektív én eltűnéséből adódik, hanem az én tárgyként észlelésének (materiális embodiment) zavarának köszönhető. A demens betegek egyénisége és ágenciájá egyre inkább a külvilág visszajelzéseire és segítségére szorul, testük magától értetődő jellege megkérdőjeleződik, amely lelassulásként és ürességként jelenik meg tapasztalataikban (Kontos és Martin 2013). A személyiség/egyéniség állandósága, a személyiség, mint a szokások megtestesülésének rendszere ugyanakkor a kognitív zavarok súlyosbodásával is fennmarad (Kontos és Martin 2013; Fuchs 2020). A megtestesült memória, a testi emlékezeti funkciók épsége magyarázattal szolgálhat egyes jellegzetes demencia tünetekre, valamint a test, mint cselekvő szubjektum állandóságára (Fuchs 2020).

Nem csak degeneratív neurológiai kórképek során kap figyelmet a testiesült cselekvés tapasztalata, hanem egyes krónikus betegségek - így a szív-érrendszeri, vagy a krónikus tüdőbetegségek - esetén is. A tüdőbetegséggel élőkre is jellemző, hogy a légzés és a test fokozottabb tudatossága (a légzés ritmusa, hangja, a légzés megtestesült tapasztalata és a test

\footnotetext{
${ }^{1}$ A Parkinson kór/szindróma (PD) egy neurológiai, mozgásos tünetekkel, kognitív zavarokkal együtt járó tünetegyüttes, melynek jellemző tünetei az izommerevség, a tremor, valamint a mozgás meglassulása és elakadása.
} 
külvilággal való kapcsolata terén) mellett meglassulásról, fáradékonyságról, akut asztmás rohamok esetén pánik és félelem érzéséről a számolnak be (Pooler 2014; Allen-Collinson és Owton 2014). A krónikus légszomj, az akut dyspnoe, a köhögés, a köpetürítés jelen vannak mindennapi tevékenységeik során, megzavarva azok magától értetődő folyamatát, gyakran megállásra kényszerítetve őket, ezzel akadályozva a mindennapi tevékenységeket, a társas kapcsolatok megélését (Pooler 2014; Allen-Collinson és Owton 2014).

Csak úgy, mint a poszt-infaktus rehabilitációban résztvevő esetén, akik sokáig korlátozottnak élik meg aktivitásukat - teljesítményük jelentős csökkenése mellett -, a felépülést pedig zavaróan lassúnak tapasztalják (Robertson, Sheikh és Moore 2010). Robertson és munkatársai (2010) szerint a nemi szerepek megtestesülése és a társadalom által közvetített normatív nemi szerepelvárások fontos szempontot jelenthetnek a terápiák és rehabilitációs programok sikerességét tekintve hiszen például a rehabilitáció során elért és megélt nyugalom - a férfias embodimentnek megfelelően - aktív és cselekvő módon történő kialakulása fontos tényező volt a résztvevők számára (Robertson, Sheikh és Moore 2010).

Látható a fentiekben is, hogy a testi tapasztalatok, az embodiment materiális, affektív és cselekvő dimenziói, valamint a társadalmi szerepek és elvárt normáknak való megfelelés kölcsönösen hatást gyakorolnak egymásra. Különös figyelmet kaptak az embodiment társadalmi dimenziójának vizsgálatával összefüggésben, azok a tumorok, amelyek a nem megtestüléséhez köthető szerveket érintenek (prostata, emlö, méh). A nők tumoros embodiment-jére hatással van a nőiesség és női test társadalmi és történeti diskurzusa (beteg) testük észlelése, megélése, elrejtése, valamint a nemi identitásuk, szexualitásuk és nőiességük mütétet/betegséget követő megítélése során (Solbrække és Bondevik 2015; Hopwood és Hopwood 2019; Parton, Ussher és Perz 2015). A tumoros női testet másnak, idegennek, furcsának, kontrollálhatatlannak, a hagyományosan kialakított és elvárt női(es)ségtől különbözőnek észlelik, müködését és reakciót szorongással, félelemmel figyelik (Solbrække és Bondevik 2015; Parton, Ussher és Perz 2015). A hajhullás, a szőrzet elvesztése, a testsúlyváltozás, a hegesedés, az emlő(k) részleges vagy teljes hiánya, a méh eltávolítása a testükkel való kapcsolat elvesztését, női létükkel, nőiességükkel, megjelenésükkel kapcsolatos bizonytalanságot és disszonancia érzést jelent számukra (Parton, Ussher és Perz 2015; Pounders és Mason 2018; Hopwood és Hopwood 2019). A nőkhöz hasonlóan, a férfiak testiesülésére is hatással vannak egyes daganatos megbetegedések, így a prostata tumor jelenléte, kezelése, valamint a kezelések mellékhatásai. A betegség és a kezelések miatt a férfiak testi funkciói és testi igényei nagyobb ráfordított figyelmet követelnek részükről, ami - mivel nem felel meg a 
férfi nemmel kapcsolatos társadalmi elvárásoknak - kellemetlenséget és szégyent kelt bennük (Chapple és Ziebland 2002). A terápia hatásaként materiális embodiment szintjén az emlők növekedéséröl, a pénisz és a herék méretének csökkenéséről, testsúly és testalkat változásáról számoltak be, amely változások szorosan kapcsolódtak a férfiasság érzésének elvesztéséhez (Oliffe 2006). Testük változásai (függetlenül attól, hogy ténylegesen látható változásokról volte szó) hatással voltak társadalmi szerepeikre, mindennapi tevékenységeikre, társas és intim kapcsolataikra, valamint térhasználatukra (Chapple és Ziebland 2002; Oliffe 2006). A beteg férfi test, a normatív férfi nemi szerep elvárásokkal szemben - amelyek szerint izmosnak, határozottnak, aktívnak, cselekvőnek és ellenállónak kell lennie - törékennyé, erőtlenné, fáradékonnyá és “nőiessé” válik (Oliffe 2006).

Szintén kapcsolatba hozható a testiesült nem társadalmi beágyazottságával a többnyire nőket érintő anorexia, amelynek embodiment szemléletü megközelítésekor fontos szempont, mit is jelent nőként testiesülni, a női testet megélni az adott kulturális közegben (Musolino, Warin és Gilchrist 2020; Lester 1997). A soványság, mint megtestesült kontroll, önkontroll, kompetencia jelképe, valamint az anorexia, mint a test gyarló fizikális szükségletein való felülemelkedés, a női természet és impulzivitás legyőzése, a nőiesség megtestesült szimbólumainak (mell, csípő és menstruáció) eltüntetése válasz is lehet a genderrel, a szexualitással, autonómiával és identitással kapcsolatos kulturális elvárásokra (Lester 1997; Musolino, Warin és Gilchrist 2020). Éppen ezért az evészavarokkal együtt járó rituálék és evési gyakorlatok megszüntetése nem csak azért nehéz, mert azok, az anorexiás személyek cselekvő embodimentjének részévé válnak (mint magától értetődő, szorongáscsökkentő, otthonosságot nyújtó testi gyakorlatok, amelyek segítséget jelentenek a mindennapokkal való megküzdésben), hanem azért is mert megkövetel egyfajta függetlenedést egyes társadalmi és kulturális hatásoktól (Musolino, Warin és Gilchrist 2020; Lester 1997).

Nem csak betegséek, hanem a természetes testi változások, így az életkorral járó változások is összefüggnek a társadalmi embodiment-tel. Ussher (2008) a (peri)menopauzával kapcsolatos diskurzus hiányára, valamint a változókor embodiment-jében megjelenő kulturális különbségekre hívja fel a figyelmet. A perimenopauza okozta testi változások esetenként szomorúsággal és veszteségérzéssel járnak a nők egy része számára, mivel nőiességük, attraktivitásuk elvesztéseként élik meg, mások ugyanakkor a testükkel való szorosabb kapcsolatról, fokozott érzékenységről és saját testük jobb elfogadásáról számolnak be (Jones 1994). A fentiek miatt fontos, hogy a változókorral járó tapasztalatokat, testérzeteket ne egy puszta hormonális "zavarként", medikalizáló modellben lássuk és "kezeljük", hanem kellő 
figyelmet fordítsunk az azokat övező társas, társadalmi, kulturális hatásokra, hiszen azok nagyban befolyásolják, hogyan értelmezzük és éljük meg testi érzeteinket (Ussher 2008).

\section{Zárógondolatok}

A fenti példákból úgy gondolom, hogy az embodiment paradigma az orvostudományban hozzájárulhat a betegségek, vagy testi állapotok jobb megértéséhez, valamint a terápiák, beavatkozások fejlesztéséhez. A betegségek mélyebb megértéséhez túl kell tekintenünk a puszta fiziológiai, biológiai, determinisztikus modelleken és fontos több figyelmet fordítanunk a betegségek kulturális, történeti, szociális és társas környezeti hatások keresztmetszetében formálódó, testiesült (betegség)tapasztalatára. Az embodiment paradigma segíthet abban, hogy egyfajta fenomenológiai nézőpontot alkalmazzunk és ezáltal közelebb kerüljünk a betegek saját létállapotához (Nemes 2015). Ennek kialakításában és elsajátításában támogatást nyújthatnak azok a beteg(ség) beszámolók, melyeket elismert szakemberek, mint S. Kay Toombs, Ann Oakley, Kathlyn Conway, Jill Bolte Taylor vagy Oliver Sacks osztanak meg velünk saját tapasztalataikról.

Figyelembe kell vennünk, hogy a beteg, sérült, vagy fájdalmas test már nem pusztán a tudattalan észlelések hálójában, a háttérbe húzódva, észrevétlen cselekvőként van jelen, tudattalanul és magától értetődően, hanem az észlelés fókuszában, mint idegen, furcsa tárgyként, tárgyi valójában kerül megtapasztalásra. Ahogy Fuchs és Schlimme (2009) szerint a mentális betegségeket nem szabad puszta "agyi diszfunkciónak" tekintenünk, hanem az ember világban való létének zavaraként, úgy a betegségekre, mint testi állapotokra is lényeges az ember világban való létezésének számos árnyalattal átitatott tükrében tekinteni (Wilde 2003). Ezek a testiesült tapasztalatok átszővik az érintettek mindennapjait, hatásukra a személynek és környezetében élőknek - meg kell tanulnia rövid, vagy akár hosszú távon is együtt élni az új észlelésekkel, az új testtel, egy megváltozott, beteg, sérült, vagy hiányos testtel. A betegek testiesült tapasztalatai betegségükről, tüneteikről fontos adalékkal szolgálnak a betegségek patomechanizmusának és kialakulásának teljeskörübb értelmezéshez, az egészségügyi egyenlőtlenségek megértéséhez, valamint a terápiás beavatkozások és gyógyító tevékenység holisztikusabbá tételéhez, ezzel segítenek minket a betegközpontú orvoslás megvalósításában. A betegközpontú ellátás részeként továbbá, a betegek megtestesült tapasztalatait, érzeteit, igényeit tekintetbe vevő, bármely embodiment dimenziót szem előtt tartó és támogató terápiás eljárások segíthetik a betegek saját testükhöz, így önmagukhoz, valamint másokhoz való 
kapcsolódását ezáltal csökkenthetik a szorongást és pozitívan befolyásolhatják a terápiás együttmüködést (Kontos 2005; Kontos és Martin 2013; Hopwood és Hopwood 2009). 


\section{Hivatkozott irodalom}

Aho Kevin A (2013): Depression and embodiment: phenomenological reflections on motility, affectivity, and transcendence. Medicine, health care, and philosophy 16(4): 751-759. DOI:https://doi.org/10.1007/s11019-013-9470-8.

Allen-Collinson, Jacquelyn és Helen Owton (2012): Take a deep breath: Asthma, sporting embodiment, the senses and "auditory work." International Review for the Sociology of Sport 49(5): 592-608. DOI:https://doi.org/10.1177/1012690212463918.

Argentieri, M Austin (2018): Embodiment and Ontologies of Inequality in Medicine. Body \& Society 24(3): 125-152. DOI:https://doi.org/10.1177/1357034x17746468.

Bahler, Brock (2019): What Hand Transplantation Teaches Us About Embodiment. AMA Journal of Ethics 21(11), E996-1002. DOI:https://doi.org/10.1001/amajethics.2019.996.

Bovet, Pierre és Josef Parnas (1993): Schizophrenic Delusions: A Phenomenological Approach. Schizophrenia Bulletin 19(3):579-597. DOI:http://dx.doi.org/10.1093/schbul/19.3.579.

Chapple, Alison, és Sue Ziebland (2002): Prostate cancer: embodied experience and perceptions of masculinity. Sociology of Health \& Illness 24(6):820-841. DOI: https://doi.org/10.1111/1467-9566.00320.

De Pasquale Concetta, Massimiliano Veroux, Luisa Indelicato, Nunzia Sinagra, Alessia Giaquinta, Michelle Fornaro, Pierfrancesco Veroux és Maria Luisa Pistorio (2014): Psychopathological aspects of kidney transplantation: Efficacy of a multidisciplinary team. World Journal of Transplantation 4(4): 267-75. DOI: https://doi.org/10.5500/wjt.v4.i4.267.

Fuchs, Thomas (2020): Embodiment and personal identity in dementia. Medicine, Health Care and Philosophy 23(4): 665-676. DOI: https://doi.org/10.1007/s11019-020-09973-0.

Fuchs, Thomas és Jann E Schlimme (2009) Embodiment and psychopathology: a phenomenological perspective. Current Opinion in Psychiatry 22(6): 570-575. DOI: https://doi.org/10.1097/yco.0b013e3283318e5c.

Gibson, Grant, és Ciara Kierans (2017): Ageing, masculinity and Parkinson's disease: embodied perspectives. Sociology of health \& illness 39(4): 532-546. https://doi.org/10.1111/14679566.12508 .

Grīnfelde, Māra (2018): The Four Dimensions of Embodiment and the Experience of Illness. AVANT. The Journal of the Philosophical-Interdisciplinary Vanguard 9(2): 107-127. DOI: https://doi.org/10.26913/avant.2018.02.07.

Hopwood, Penelope és Nick Hopwood (2018): New challenges in psycho-oncology: An embodied approach to body image. Psycho-Oncology 28(2): 211-218. DOI: https://doi.org/10.1002/pon.4936.

Jones, Jill (1994): Embodied Meaning. Social Work in Health Care 19(3-4): 43-65. DOI: https://doi.org/10.1300/j010v19n03_03.

Kontos, Pia, és Wendy Martin (2013) Embodiment and dementia: Exploring critical narratives of selfhood, surveillance, and dementia care. Dementia 12(3): 288-302. DOI: https://doi.org/10.1177/1471301213479787. 
Kontos, Pia C (2005): Embodied selfhood in Alzheimer's disease: Rethinking person-centred care. Dementia 4(4): 553-570

Leder, Drew (1984): Medicine and Paradigms of Embodiment. Journal of Medicine and Philosophy 9(1): 29-44. DOI: https://doi.org/10.1093/jmp/9.1.29.

Lester, Rebecca J (1997): The (dis)embodied self in anorexia nervosa. Social Science \& Medicine 44(4): 479-489. DOI: https://doi.org/10.1016/s0277-9536(96)00166-9.

Musolino, Connie Marguerite, Megan Warin és Peter Gilchrist (2020): Embodiment as a Paradigm for Understanding and Treating SE-AN: Locating the Self in Culture. Frontiers in Psychiatry 11. DOI: https://doi.org/10.3389/fpsyt.2020.00534.

Neiterman, Elena (2013): Sharing bodies: the impact of the biomedical model of pregnancy on women's embodied experiences of the transition to motherhood. Healthcare Policy SP(9): 11225. DOI: https://doi.org/10.12927/hcpol.2013.23595.

Nemes, László (2015): A betegség mint fenomenológiai tapasztalat. Nagyerdei Almanach 2015(1): 21-33.

Nisticò, Rita, Antonio Cerasa, Giuseppe Olivadese, Riccardo Dalla Volta, Marianna Crasà, Roberta Vasta, Vera Gramigna et al (2019): The embodiment of language in tremor-dominant Parkinson's disease patients. Brain and cognition 135. 103586. DOI: https://doi.org/10.1016/j.bandc.2019.103586.

Oliffe, John (2006): Embodied masculinity and androgen deprivation therapy. Sociology of Health and Illness 28(4): 410-432. DOI: https://doi.org/10.1111/j.1467-9566.2006.00499.x.

Parton, Chloe M., Jane M. Ussher és Janette Perz (2016): Women's Construction of Embodiment and the Abject Sexual Body After Cancer. Qualitative Health Research, 26. 490503. https://doi.org/10.1177/1049732315570130.

Pooler, Charlotte (2014): Living With Chronic Lower Pulmonary Disease:Disruptions of the Embodied Phenomenological Self. Global Qualitative Nursing Research 1. 2333393614548762. DOI: https://doi.org/10.1177/2333393614548762.

Pounders, Kathrynn és Marlys Mason (2018): Embodiment, Illness, and Gender: The Intersected and Disrupted Identities of Young Women with Breast Cancer. Consumer Culture Theory 111-122. DOI: https://doi.org/10.1108/s0885-211120180000019007.

Robertson, Steve, Kay Sheikh és Andrew Moore (2010): Embodied masculinities in the context of cardiac rehabilitation. Sociology of Health \& Illness 32(5): 695-710. DOI: https://doi.org/10.1111/j.1467-9566.2010.01249.x.

Ross, Emily (2018): Gestating bodies: sensing foetal movement in first-time pregnancy. Sociology of Health \& Illness 41(1): 95-111. DOI: https://doi.org/10.1111/1467-9566.12809.

Schlebusch, Lourens, Basil J. Pillay és Johan Louw (1992): Body-Image Differences in LiveRelated and Cadaver Renal Transplant Recipients. South African Journal of Psychology 22(2): 70-75. DOI: https://doi.org/10.1177/008124639202200205.

Solbrække, Kari Nyheim és Hilde Bondevik (2015): Absent organs-present selves: exploring embodiment and gender identity in young Norwegian women's accounts of hysterectomy. 
International Journal of Qualitative Studies on Health and Well-being 10(1) 26720. https://doi.org/10.3402/qhw.v10.26720.

Stähler, Tanja (2017): Exploring Pregnant Embodiment with Phenomenology and Butoh Dance. Yearbook for Eastern and Western Philosophy 2017(2) DOI: https://doi.org/10.1515/yewph-2017-0006.

Thanem, Torkild, és David Knights (2012): Feeling and speaking through our gendered bodies: embodied self-reflection and research practice in organisation studies. International Journal of Work Organisation and Emotion 5(1): 91. DOI: https://doi.org/10.1504/ijwoe.2012.048594.

Tschacher, Wolfgang, Anne Giersch, és Karl Friston (2017) Embodiment and Schizophrenia: A Review of Implications and Applications. Schizophrenia Bulletin 43(4): 745-753. DOI: https://doi.org/10.1093/schbul/sbw220.

Ussher, Jane M. (2008): Reclaiming Embodiment within Critical Psychology: A MaterialDiscursive Analysis of the Menopausal Body. Social and Personality Psychology Compass 2(5): 1781-1798. DOI: https://doi.org/10.1111/j.1751-9004.2008.00151.x.

Waskul, Dennis D és Pamela van der Riet (2002): The Abject Embodiment of Cancer Patients: Dignity, Selfhood, and the Grotesque Body. Symbolic Interaction 25(4): 487-513. DOI: https://doi.org/10.1525/si.2002.25.4.487.

Wilde, Mary H (2003): Embodied knowledge in chronic illness and injury. Nursing Inquiry 10(3): 170-176. DOI: https://doi.org/10.1046/j.1440-1800.2003.00178.x. 